\title{
Holding Financial Institutions and Companies investment Efficiency
}

\author{
Yingxue Cheng ${ }^{1, a, *}$ \\ ${ }^{1}$ Beijing Jiaotong University Accounting department, Beijing, China \\ a17120648@bjtu.edu.cn \\ *Corresponding author
}

Keywords: Combination of industrial and financial, Investment efficiency.

\begin{abstract}
This paper examines the influences of holding financial institutions on the company's investment efficiency. Using the sample of Chinese A-shares of Shanghai and Shenzhen non-financial listing companies from 2012 to 2016, I find evidence that, although holding financial institutions can reduce under-investment, it also increases over-investment, on the whole, holding financial institutions can reduce the investment efficiency.
\end{abstract}

\section{Introduction}

As China's capital market matures, more and more industry companies enter financial field. At the end of 2014, more than 590 Chinese listed companies, including Founder and Haier, and other well-known companies carried out "the integration of industry and finance", which accounted for about $17 \%$ of the total number of listed A-share companies. However, in stark contrast to practice, academics are less concerned about this phenomenon.

The existing research hasn't come to any uniform conclusion on whether "the integration of production and finance” can improve company's performance. Xu Zheng finds that the combination can help improve the operational efficiency of enterprises. Zhao Yuan argues that the integration can make companies have higher growth capabilities and worse operating performance. The main reason for this disagreement is that they ignore that the holding financial institutions make different influence on the investment efficiency in different companies, and directly explore the relationship between the holding financial institutions and their performance indicators. Corporate controlled financial institutions will increase their financing convenience and funds have a major effect on corporate investment efficiency. Consider the importance of investment to companies, this paper use Richardson's investment expectation model to examine the impact of holding financial institutions on corporate investment efficiency (Richardson, 2006) ${ }^{[1]}$.

In this regard, this article uses the sample of Chinese A-shares of Shanghai and Shenzhen non-financial listing companies from 2012 to 2016 to explore the influence of the listed company's holding financial institution on its investment efficiency. And find evidence that, although holding financial institutions can reduce under-investment, it also increases over-investment, on the whole, holding financial institutions can reduce the investment efficiency.

\section{Theory and empirical hypotheses}

According to the World Bank report, 75 percent of non-financial listed companies in China believe that financing constraints are major obstacles to their development, which is the highest proportion among 80 countries surveyed. The development of China's capital market is not yet mature, few kinds financing channels and tools for enterprises, making credit funds of financial institutions become main sources of external funds. In order to control the proportion of bad loans, financial institutions tend to lend out short-term loans and mortgage loans. Especially after the outbreak of the global financial crisis in 2007, financial institutions' lend willingness become even lower, this situation further exacerbates the external financing constraints of Chinese companies.

Under this background, non-financial companies holding financial institutions are able to stabilize the supply of credit funds, which has great significance to the development of enterprises, 
the reasons follows.

First, companies holding financial institutions can reduce information asymmetry between the two. Through the establishment of formal equity contacts with financial institutions, the information communication channels between enterprises and banks have been broadened, and information exchange has become timely. Second, holding financial institutions can affect their credit decisions. When a company holds certain percentage of shares in a financial institution, it can influence credit decisions by dispatching directors to financial institutions, thereby making it easier for enterprises to obtain more connected loans with lower interest rates. Third, holding financial institutions helps companies to enter the financial industry's relationship circle. China's current legal system and financial mechanism are still not sound. To reduce bad loans risk, financial institutions will preferentially provide loans to companies which they trust. Companies can also enhance their reputation in the credit market through holding banks.

Most investment efficiency studies have been conducted from the perspectives of under-investment and over-investment (Richardson, 2006), given that this paper also discusses how holding financial institutions affect investment efficiency from these two perspectives.

In terms of under-investment, Financing Constraints Theory believes that information asymmetry between managers and external capital providers makes the external capital cost of the enterprise higher than the internal financing cost, and high reliance on internal funds may lead to under-investment (Myers, 1984) ${ }^{[3]}$.The existence of financing constraints has made Chinese listed companies' investment spending generally lower than the optimal level. Given the strong positive correlation between cash flow and investment (Hoshi, 1991; Fazzari,2000; Hirth,2011) ${ }^{[4-6]}$, companies hold financial institutions can make them obtain more related loans with lower interest rates and reduce the level of financing constraints. Therefore, holding financial institutions can alleviate the problem of under-investment.

In terms of over-investment, companies generally have expansionary impulses in practice (Meckling,1986) ${ }^{[2]}$. The more funds companies can use to invest, the greater the possibility of over-investment. While corporate holding financial institutions can greatly reduce the uncertainty of future financing. Enterprises need not worry about the shortage of funds caused by excessive investment, which encourage them to continue to expand their investment scale, and as a result, holding financial institutions may exacerbate over-investment. Based on these, the following assumptions are made.

Hypothesis 1a: Holding financial institutions can alleviate under-investment.

Hypothesis 1b: Holding financial institutions may exacerbate under-investment.

\section{Research methodology}

\subsection{Research samples and data sources}

This article selected the 2012-2016 China Shenzhen and Shanghai A-share non-financial listed company as the research objects, and explored the effect of the holdings financial institutions on their investment efficiency. There were total 7654 observations, of which 4,482 observations were in the under-investment sample group and 3,172 observations in the over-investment sample group. In order to eliminate the influence of extreme values on the regression results, the main variables are processed up and down $1 \%$ quantiles. The data came from CSMR database.

\subsection{Models and main variables}

This paper adopted Richardson investment expectation model. The residual of the model is used as the proxy variable to measure the investment efficiency of enterprises. Positive residual represents of excessive investment and negative residual means under-investment. What's more, the greater residual's absolute value, the greater degree of deviation from the normal level of corporate investment. The model is as follows:

$$
\mathrm{INV}_{\mathrm{t}}=\alpha_{0}+\alpha_{1} \mathrm{Q}_{\mathrm{t}-1}+\alpha_{2} \operatorname{Lev}_{\mathrm{t}-1}+\alpha_{3} \text { Size }_{\mathrm{t}-1}+\alpha_{4} \text { Age }_{\mathrm{t}-1}+\alpha_{5} \text { Ret }_{\mathrm{t}-1}+\alpha_{6} \text { Cash }_{\mathrm{t}-1}
$$




$$
+\alpha_{7} \operatorname{Inv}_{\mathrm{t}-1}+\text { Yeardummy+Indusdummy }+\varepsilon_{\mathrm{t}} .
$$

According to the positive and negative residuals of the model (1), the samples are divided into two groups, over-investment (Inv_o ) and under-investment (Inv_u )to respectively explore the impact of holding financial institutions on company's investment efficiency. The models are as follows.

$$
\begin{gathered}
\text { Inv_O }_{\mathrm{t}}=\alpha_{0}+\alpha_{1} \text { Fin }_{\mathrm{t}}+\alpha_{2} \text { Contro }_{\mathrm{t}-1}+\text { Yeardummy }+ \text { Indusdummy }+\varepsilon_{\mathrm{t}} . \\
\text { Inv_U }_{\mathrm{t}}=\alpha_{0}+\alpha_{1} \text { Fin }_{\mathrm{t}}+\alpha_{2} \text { Contro }_{\mathrm{t}-1}+\text { Yeardummy }+ \text { Indusdummy }+\varepsilon_{\mathrm{t}} .
\end{gathered}
$$

\begin{tabular}{|c|c|c|c|}
\hline & Variable Name & $\begin{array}{l}\text { Variable } \\
\text { Symbol }\end{array}$ & Definition \\
\hline \multirow{2}{*}{$\begin{array}{l}\text { Dependent } \\
\text { variable }\end{array}$} & Under-investment & Inv_u & $\begin{array}{l}\text { The residual of the investment expectation model } \\
\qquad \varepsilon<0\end{array}$ \\
\hline & Over-investment & Inv_o & $\begin{array}{l}\text { The residual of the investment expectation model } \\
\qquad \varepsilon>0\end{array}$ \\
\hline $\begin{array}{c}\text { Independent } \\
\text { variable }\end{array}$ & $\begin{array}{l}\text { Stock-holding financial } \\
\text { institution }\end{array}$ & Fin & $\begin{array}{l}\text { If the company holds more than } 20 \% \text { of the shares of } \\
\text { the financial institution, it is } 1 \text {, otherwise it is } 0 .\end{array}$ \\
\hline \multirow{9}{*}{$\begin{array}{l}\text { Control } \\
\text { variable }\end{array}$} & Board Size & Board & The number of board members in the company \\
\hline & Independent director ratio & Ratio_Dirt & $\begin{array}{c}\text { Percentage of independent directors in corporate } \\
\text { boards }\end{array}$ \\
\hline & Combining two positions & Dual & $\begin{array}{l}\text { If the chairman and the general manager are the same } \\
\text { person, it is } 1 \text {, otherwise it is } 0\end{array}$ \\
\hline & Return on Assets & Roa & Net profit/total assets at the end of the year \\
\hline & Business scale & Size & The natural logarithm of company's total assets \\
\hline & Listing time & Age & The company's listing period \\
\hline & Dividend payment & Didven & $\begin{array}{l}\text { If the company issue cash dividends during the year,it } \\
\text { is } 1 \text {, otherwise it is } 0\end{array}$ \\
\hline & Years & Yeardummy & $\begin{array}{l}\text { Sample period 2012-2016, introducing } 4 \text { annual } \\
\text { virtual variables }\end{array}$ \\
\hline & Industry & Indusdummy & $\begin{array}{l}\text { Classified according to the classification criteria of } \\
\text { the China Securities Regulatory Commission, } \\
\text { manufacturing industry classified by secondary codes }\end{array}$ \\
\hline
\end{tabular}

Table 1. The main variable definition table

\section{Regression results and analysis}

\subsection{Descriptive statistics}

Table 2 shows the descriptive statistics of relevant variables. The total sample has a total of 7654 observations, of which there are 4482 observations in the under-investment sample group and 3172 observations in the over-investment sample group, indicating that the under-investment problem in China is more common. The results are similar to researches of Xie Deren and Wu Chaopeng which initially prove the reliability of this paper's research data.

Table 2. Descriptive statistics

\begin{tabular}{cccccc}
\hline Variable & $\begin{array}{c}\text { Number of } \\
\text { samples }\end{array}$ & Average & Standard deviation & $\begin{array}{c}\text { The minimum } \\
\text { value }\end{array}$ & $\begin{array}{c}\text { The maximum } \\
\text { value }\end{array}$ \\
\hline Inv_u & 4481 & 3.343 & 3.181 & 0.011 & 18.312 \\
\hline Inv_o & 3172 & 4.000 & 4.278 & 0.001 & 26.454 \\
\hline Fin & 7653 & 0.037 & 0.190 & 0 & 1.000 \\
\hline Board & 7653 & 2.153 & 0.198 & 0.333 & 0.571 \\
\hline Ratio_Dirt & 7653 & 0.372 & 0.053 & 0 & 1.000 \\
\hline Dual & 7653 & 0.244 & 0.429 & 0.144 & 0.209 \\
\hline Roa & 7653 & 0.041 & 0.052 & 8.508 & 11.277 \\
\hline Size & 7653 & 9.596 & 0.548 & 0 & 1.000 \\
\hline Didven & 7653 & 0.743 & 0.437 & &
\end{tabular}




\subsection{Regression analysis}

Table 3 shows the regression results, which are divided into two groups, under-investment and over-investment.

Table 3. Main test regression results

\begin{tabular}{|c|c|c|c|c|}
\hline \multirow{3}{*}{$\begin{array}{c}\text { Explained } \\
\text { variable } \\
\text { Model }\end{array}$} & \multicolumn{4}{|c|}{ Investment efficiency } \\
\hline & \multicolumn{2}{|c|}{ Inv_u } & \multicolumn{2}{|c|}{ Inv_o } \\
\hline & (1) & (2) & (3) & (4) \\
\hline Fin $_{t}$ & $-0.041^{* * *}$ & $-0.040^{* * *}$ & $0.050^{* * *}$ & $0.055^{* * *}$ \\
\hline Board $_{\mathrm{t}-1}$ & & -0.006 & & -0.020 \\
\hline Ratio_Dirt ${ }_{t-1}$ & & $0.034^{*}$ & & 0.003 \\
\hline Dual $_{\mathrm{t}-1}$ & & -0.015 & & $0.051^{* * *}$ \\
\hline Size $_{\mathrm{t}-1}$ & & $-0.063^{* * *}$ & & $-0.068^{* * *}$ \\
\hline $\mathrm{Lev}_{\mathrm{t}-1}$ & & -0.027 & & -0.006 \\
\hline Roa $_{\mathrm{t}-1}$ & & -0.002 & & $0.040^{*}$ \\
\hline Didven $_{\mathrm{t}-1}$ & & $-0.114^{* * *}$ & & $-0.036^{*}$ \\
\hline $\mathrm{C}$ & 0.000 & -0.096 & 0.000 & 0.013 \\
\hline Industry effect & & control & & control \\
\hline Annual effect & & control & & control \\
\hline Obs & 4482 & 4482 & 3172 & 3172 \\
\hline F-value & 8.33 & 10.96 & 7.79 & 7.08 \\
\hline P-value & 0.004 & 0.000 & 0.005 & 0.000 \\
\hline
\end{tabular}

Model (1) explores the relationship between holding financial institution and under-investment without controlling other factors, both of which are negatively related at $1 \%$ level of significance, indicating that holding financial institutions has less under-investment compared with these no holding companies, which initially supports Hypothesis 1a. Model (2) introduces control variables on the basis of model (1), including corporate governance and financial characteristics. Holding financial institutions is still negatively related to under-investment at $1 \%$ level of significance, which further supported Hypothesis 1a, that is to say, holding financial institutions can alleviate the company's under-investment. Model (3) explores the relationship between holding financial institution and over-investment without controlling other factors and finds that the two are positively related at the $1 \%$ level of significance, indicating that holding financial institutions may aggravate over-investment, which initially supports Hypothesis 1b. Model(4) introduces control variables on the basis of model (3) and finds that holding financial institutions is still positively correlated with over-investment at the level of $1 \%$ significance, further supporting hypothesis $1 \mathrm{~b}$.

\section{Conclusion}

This article explores the effect of the stock-holding financial institutions on the efficiency of corporate investment efficiency in Shanghai and Shenzhen A-share non-financial listed companies during 2012-2016, and finds that the stock-holding financial institutions have the dual role of alleviating under-investment and increasing over-investment. For the under-invested enterprises, stock-holding financial institutions can increase the availability of corporate funds, and thus ease the financing constraints faced by the company, ease the company's lack of investment, increase its investment efficiency, however for the over-invested enterprises, stock-holding financial institutions enable companies to obtain more credit funds with lower interest rates, which will further aggravate the excessive investment of enterprises and reduce their investment efficiency.

\section{References}

[1] R. Scott, Over-investment of free cash flow, Review of Accounting Studies, vol.11, pp.159-189,2006. 
[2] J. Meckling, Agency Costs of Free Cash Flow, Corporate Finance, and Takeovers, American Economic Review, vol.2, pp.323-329,1986.

[3] S. Myers and N. Majluf, Corporate Financing and Investment Decisions When Firms Have Information That Investors Do Not Have, Journal of Financial Economics, vol.13, pp.187-221,1984.

[4] S. M. Fazzari and R. G. Hubbard, Investment-Cash Flow Sensitivities are Useful: A Comment on Kaplan and Zingales, Quarterly Journal of Economics, vol.2, pp.695-705, 2000.

[5] S. Hirth and M. Viswanatha, Financing constraints, cash-flow risk, and corporate investment, Journal of Corporate Finance, vol.5, pp.1496-1509, 2011.

[6] T. Hoshi and A. Kashyap, Corporate structure, liquidity, and investment : evidence from Japanese panel data, Quarterly Journal of Economic, vol.1, pp.33-60, 1991. 